\title{
Antimicrobial Activities of Irvingia gabonensis Leaf and Cyperus esculentus Extracts on Some Selected Isolates
}

\author{
Arikekpar Ibemologi*and Alade Tolu lope \\ Department of Medical Laboratory Science, Niger Delta University Wilberforce Island Amassoma, Nigeria
}

*Corresponding author: Arikekpar Ibemologi, Department of Medical Laboratory Science, Faculty of Basic Medical Sciences, Niger Delta University Wilberforce Island Amassoma. P.M.B. 071, Bayelsa State, Nigeria.

To Cite This Article: Arikekpar Ibemologi, Antimicrobial Activities of Irvingia gabonensis Leaf and Cyperus esculentus Extracts on Some Selected Isolates. 2020 - 7(3). AJBSR.MS.ID.001148. DOI: 10.34297/AJBSR.2020.07.001148.

Received: 眥 January 22, 2020; Published: 制 February 18, 2020

\begin{abstract}
Bacterial resistance to antibacterial drugs in the treatment of some bacterial infections have become a menace that is causing untold health challenges to patients. The antibacterial activity of ethanolic extract of tiger nut (Cyperus Esculentus) and Bush mango (Irvingia Gabonensis) against candida albicans, Echerichia coli, Pseudomonas sp, Salmonella sp and Staphylococcus aureus was evaluated using agar-well diffusion, Minimum Inhibitory Concentration (M.I.C) and Minimum Bacteriocidal Concentrations (M.B.C) methods. Echerichia coli had the highest total colony count of $1.3 \times 10^{11}$ Colony forming unit $/ \mathrm{ml}(\mathrm{Cfu} / \mathrm{ml})$ followed by Pseudomonas sp $\left(8.8 \times 10^{10} \mathrm{Cfu} / \mathrm{ml}\right)$ and Staphylococcus aureus $\left(6.7 \mathrm{X} 10^{10}\right)$ at $1.0 \mathrm{E}-09$ dilution, but in the 1.0E-10 dilution, Pseudomonas sp was highest with $9.7 \times 10^{11} \mathrm{Cfu} / \mathrm{ml}$ followed by E. coli $\left(9.0 \mathrm{X} 10^{11} \mathrm{Cfu} / \mathrm{ml}\right)$.The result from the comparative agar well diffusion assay of Tiger nut and Irvingia crude extracts showed that the extracts have antimicrobial activity against some of the test isolates. Pseudomonas spp. were susceptible to the tiger nut extract ( $10 \%$ and $20 \%$ ) with the diameter of Zone of Inhibition (ZOI) of $18.0 \pm 0 \mathrm{~mm}$ and $18.5 \pm 1.5 \mathrm{~mm}$. While Echerichia coli, Pseudomonas sp, Salmonella sp and Staphylococcus aureus showed susceptibility to the Irvingia (10\%) crude extract with ZOI diameters of $13 \pm 2 \mathrm{~mm}, 15.5 \pm 0.5 \mathrm{~mm}, 16.5 \pm 1.5 \mathrm{~mm}$ and $16.5 \pm 0.5 \mathrm{~mm}$ respectively. Pseudomonas also exhibited susceptibility to the Tiger nut (20\%) crude extract having a ZOI diameter of $18.5 \pm 1.5 \mathrm{~mm}$ while E.coli, Pseudomonas spp, Salmonella spp and Staphylococcus aureus were susceptible to Irvingia (20\%) crude extract, revealing ZOI diameters of $15.5 \pm 0.5 \mathrm{~mm}, 19 \pm 0 \mathrm{~mm}, 18 \pm 1 \mathrm{~mm}$ and $15 \pm 0$ mm respectively The Minimum Inhibitory Concentration (MIC) of both extracts was 50\% for all organisms, while the Minimum Bacteriocidal Concentration (MBC) of both crude extracts was $50 \%$ for Staphylococcus aureus only. The dilution factors and total colony counts from 1.0E-09 and 1.0E-10 dilutions of 5 test isolates. where statistically analyzed with ANOVA, and the P. values where 0.13 and 0.4 respectively were significant.
\end{abstract}

Keywords: Bush mango; Tiger nut; antibacterial activity; Zone of inhibition; Ethanolic extract

\section{Background}

The rise of antibiotic resistant microorganism is one of the severe problems in health care system of the world and infectious diseases are the second most serious causes of death worldwide. Thus, it is essential to find new compounds that have antimicrobial properties by screening plant species to detect those that can synthesize new drugs [1]. Thus, this study is carried out to determine the antimicrobial activity of bush mango and tiger nut extracts on some selected microorganisms.

Tiger nut (Cyperus esculentus) is a tuber that is consumed widely in Nigeria and in various other parts of West and East Africa [2]. It is eaten raw or roasted, used as hog feed or pressed for its juice to make a beverage [3].Tiger nuts are valued for their highly nutritious starch content, dietary fibre and carbohydrate and are rich in sucrose (17.4-20.0\%), fat (25.5\%), protein (8.0\%). Tiger nut is also rich in mineral elements such as sodium, calcium, potassium, magnesium, zinc and traces of copper [4].

Bush mango (Irvingia gabonensis) belongs to the Irvingiaceae plant family [5]. Bush mango leaf/root extracts have documentary inhibitory activity against several bacteria and fungi. It possesses antimicrobial effects against Escherichia coli and Staphylococcus aureus [6]. Tiger nuts and bush mango have antibacterial activity against Salmonella, Escherichia coli. Candida albicans, Staphylococcus aureus and Pseudomonas [7].

\section{Methods}

Two hundred and twenty-five (225 grams) each of processed plant materials (Irvingia gabonesis and Tiger nut powders) were 
soaked differently in $400 \mathrm{ml}$ of $80 \%$ absolute ethanol in $500 \mathrm{ml}$ conical flasks. The preparation was processed further using the model of [8] with slight modification. Plant extract filtrate of 10\%, 20\% and $50 \% \mathrm{v} / \mathrm{v}$ of Irvingia gabonesis and Tiger nut was prepared using method by [9] with slight modification.

Bacterial test colonies were introduced into $5 \mathrm{mls}$ of tryptic soy broth, incubated overnight at $37^{\circ} \mathrm{C}$ and centrifuged. Followed by standardization and serial dilution using stardard microbiological procedures. Agar well diffussion assay was done using double strenght Mueller Hinton Agar (MHA), and five wells were made with the aid of a steriized cork borer $6 \mathrm{~mm}$ in diameter. Molten nutrient agar was dispensed to prevent plant extract diffusion to the next well, 200 microlitres of the (Irvingia a. extract 10\%, 20\%, \& $50 \%$ ) were dispensed into the various holes and Cyperus esculentus (Tiger nut 10\%, 20\%, \& 50\%) was also pipetted into various holes in another MHA plate. Distilled water was used as Negative control and Augumentin was used as positive control. The experiment was done in duplicates and the plates were kept for about 1hour at room temperature and incubated at $37 \%$ for $18-24$ hours. The diameter of zones of inhibition was measured after incubation [8].

The model of [8] was adopted with slight modification for minimum inhibitory concentration. Ten milliliter $(10 \mathrm{ml})$ volume of double strength molten Mueller Hinton agar after autoclaving at $45^{\circ} \mathrm{C}$ was dispensed into sterile universal bottle and $10 \mathrm{ml}$ of the Irvingia gaboonesis plant extract was added. Equal volume of the test plant extract in graded concentration of $20 \%, 30 \%, 50 \%$ and $100 \%$ was made. These were poured aseptically into sterile petri-dishes and were allowed to solidified at room temperature, for one hour with the lid of the petri-dishes slightly raised.

Twenty microlitre of standardized test bacteria were impregnated/ inoculated aseptically on the sterilized Whatman no 1 filter paper discs, placed on the agar surface at equidistance in duplicate for each concentration of the test plant extracts.

These were incubated at $37^{\circ} \mathrm{C}$ for $18-24$ hours. The minimum inhibitory concentration value was taken as the least concentration of the plant extract at 50\%, showing no detectable growth.

Augmentin was used as standard antibiotic. The minimum bacteriocidal was determined by transferring inoculated bacterial discs into a sterile $3 \mathrm{ml}$ recovery of Luria Bertani broth from the plant extract concentration that showed no visible growth from the M.I.C determination.

These were incubated at $37^{\circ \mathrm{c}}$ for 72 hours. The least concentration of the plant extracts that showed no bacterial growth in the recovery liquid medium were $50 \%$ was taken as the M.B.C.

\section{Results}

(Figure 1) shows Total Colony Count of Isolated organisms. The graph depicts the highest total colony count by E. coli $(1.3 \mathrm{X}$ $10^{11}$ Colony forming unit/ml) followed by Pseudomonas spp (8.8 X $\left.10^{10} \mathrm{Cfu} / \mathrm{ml}\right)$ and Staphylococcus aureus $\left(6.7 \times 10^{10}\right)$ at $1.0 \mathrm{E}-09$ dilution, but in the 1.0E-10 dilution, Pseudomonas spp was highest with $9.7 \mathrm{X} 10^{11} \mathrm{Cfu} / \mathrm{ml}$ followed by E. coli $(9.0 \mathrm{X} 1011 \mathrm{Cfu} / \mathrm{ml})$.

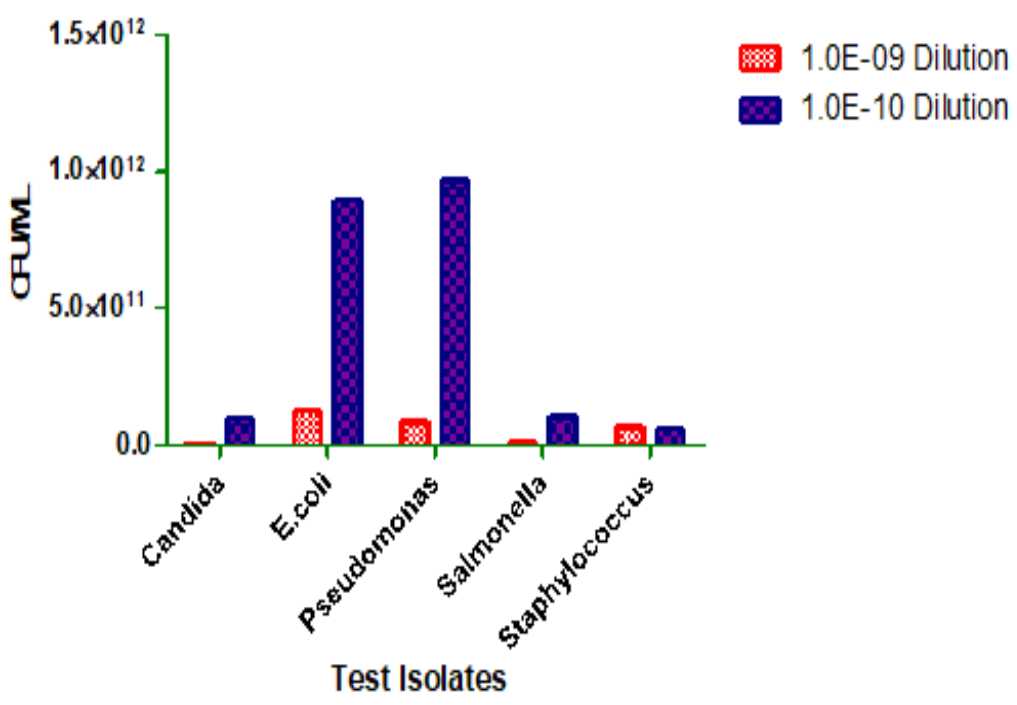

Figure 1: Total Colony Count of Test Isolates.

(Table 1) shows the Comparative Agar well diffusion assay of Tiger nut and Irvingia Crude Extracts against Test Isolates. The result of the susceptibility test of the organisms to the extracts showed that the extracts had antimicrobial activity against some of the test isolates. Pseudomonas spp showed antimicrobial susceptibility to the Tiger nut (10\%) crude extract with a zone of inhibition (ZOI) 
diameter of $18.0 \pm 0 \mathrm{~mm}$ while Echerichia coli, Pseudomonas spp, Salmonellaspp and Staphylococcus aureus showed susceptibility to the Irvingia (10\%) crude extract with ZOI diameters of $13 \pm 2 \mathrm{~mm}$, $15.5 \pm 0.5 \mathrm{~mm}, 16.5 \pm 1.5 \mathrm{~mm}$ and $16.5 \pm 0.5 \mathrm{~mm}$ respectively. Pseudomonas also exhibited susceptibility to the Tiger nut (20\%) crude extract having a ZOI diameter of $18.5 \pm 1.5 \mathrm{~mm}$ while E.coli, Pseu- domonas spp, Salmonella spp and Staphylococcus aureus were susceptible to Irvingia (20\%) crude extract, revealing ZOI diameters of $15.5 \pm 0.5 \mathrm{~mm}, 19 \pm 0 \mathrm{~mm}, 18 \pm 1 \mathrm{~mm}$ and $15 \pm 0 \mathrm{~mm}$ respectively. All test isolates showed resistance to the both $50 \%$ crude extracts of Tiger nut and Irvingia.

\begin{tabular}{|c|c|c|c|c|c|c|c|c|}
\hline Organism & $\begin{array}{c}\text { Tiger nut } \\
(10 \%)\end{array}$ & Tiger nut (20\%) & Irvingia (50\%) & Irvingia (10\%) & $\begin{array}{c}\text { Irvingia } \\
(20 \%)\end{array}$ & $\begin{array}{c}\text { Irvingia } \\
\text { (50\%) }\end{array}$ & $\underset{\text { tin }}{\text { Augumen- }}$ & $\mathrm{D} / \mathrm{H}_{2} \mathrm{O}(50 \%)$ \\
\hline Candida & $5.0 \pm 5(\mathrm{R})$ & $0(\mathbf{R})$ & $0.5 \pm 0.5(\mathbf{R})$ & $11.5 \pm 0.5$ (I) & $12.5 \pm 0.5$ (I) & $5 \pm 0(\mathbf{R})$ & $30 \pm 0(\mathbf{S})$ & $0(\mathbf{R})$ \\
\hline E. coli & $0(\mathbf{R})$ & $0(\mathrm{R})$ & $1.5 \pm 0.5$ (R) & $13 \pm 2(\mathbf{S})$ & $15.5 \pm 0.5$ (S) & $\begin{array}{l}7.5 \pm 0.5 \\
\text { (R) }\end{array}$ & $\begin{array}{c}22.5 \pm 2.5 \\
\text { (S) }\end{array}$ & $0(\mathbf{R})$ \\
\hline Pseudo & $18.0 \pm 0(\mathbf{S})$ & $18.5 \pm 1.5$ (S) & $6.0 \pm 1(\mathrm{R})$ & $15.5 \pm 0.5$ (S) & $19 \pm 0$ (S) & $\begin{array}{c}6.5 \pm 1.5 \\
\text { (R) }\end{array}$ & $17 \pm 0$ (R) & 0 (R) \\
\hline Salmonella & 0 (R) & $10.0 \pm 0$ (I) & $.0 \pm 1.4(\mathbf{R})$ & $16.5 \pm 1.5(\mathrm{~S})$ & $18 \pm 1(S)$ & $5 \pm 0$ (R) & $0(\mathbf{R})$ & $0(\mathrm{R})$ \\
\hline $\begin{array}{l}\text { Staphylococ- } \\
\text { cus }\end{array}$ & $0(\mathbf{R})$ & $0(\mathbf{R})$ & $2.5 \pm 2.5$ (R) & $16.5 \pm 0.5$ (S) & $15 \pm 0(\mathbf{S})$ & $\begin{array}{l}4.5 \pm 0.5 \\
\text { (R) }\end{array}$ & $20 \pm 0(\mathbf{R})$ & $0(\mathbf{R})$ \\
\hline
\end{tabular}

Table 2: Minimum Inhibitory Concentration (MIC) and Minimum Bacteriocidal Concentration (MBC).

\begin{tabular}{|c|c|c|c|c|}
\hline \multirow{2}{*}{ Test Organisms } & \multicolumn{2}{|c|}{ MIC (vol/vol) } & \multicolumn{2}{c|}{ M.C.B (vol/vol) } \\
\cline { 2 - 5 } & Tiger Nut & Irvingia & Tiger Nut & grvingia \\
\hline Candida & 50 & 50 & growth & growth \\
\hline E.coli & 50 & 50 & growth & growth \\
\hline Pseudomonas & 50 & 50 & growth & growth \\
\hline Salmonella & 50 & 50 & growth & growth \\
\hline Staphylococcus & 50 & 50 & rowth \\
\hline
\end{tabular}

(Table 2) shows the Minimum Inhibitory Concentration (MIC) and Minimum Bacteriocidal Concentration (MBC). The Minimum inhibitory concentration value from the results obtained was the $50 \%$ concentration of the Tiger nut and Irvingia crude extracts. The Minimum bacteriocidal concentration of both crude extracts was also the $50 \%$ concentration for only Staphylococcus aureus as other isolates.

Values are inhibition zone diameters (ZOI) expressed as mean \pm Standard deviation; Resistant(R) $=\mathrm{ZOI} \leq 8 \mathrm{~mm}$; Intermediate (I) $=\mathrm{ZOI}=9-12 \mathrm{~mm}$; Susceptible $(\mathrm{S})=\mathrm{ZOI} \geq 13 \mathrm{~mm}$; \%= volume per volume concentration; Augumentin= positive control; Distilled water= negative control. Pseudo=Pseudomonas $s p$

The Minimum inhibitory concentration value from the results obtained was the 50\% concentration of the Tiger nut and Irvingia crude extracts. The Minimum bacteriocidal concentration of both crude extracts was also the $50 \%$ concentration for only Staphylococcus aureus as other isolates grew in recovery broth.

Data between the groups were analyzed using Graph pad Prism software with ANOVA from results of total plate counts of 1.0E-09 and 1.0E-10 dilutions of 5 test isolates. The Dilution factors and Total colony counts for the isolates accounted for $27.77 \%$ and $42.63 \%$ of the total variance respectively; and a P value of
0.13 and 0.4 respectively that are considered not to be significant.

\section{Discussion}

Tiger nut (Cyperus esculentus) and Irvingia gabonensis (bush mango) have medicinal properties which have been harnessed by traditional medicine practitioners, but only a few of these properties have been proven scientifically. However, in this present study, only the tubers and leaves of Cyperus esculentus and Irvingia gabonensis were utilized. The results from the Comparative Agar well diffusion assay of Tiger nut and Irvingia Crude Extracts revealed that the extracts have antimicrobial activity against some of the test isolates. Pseudomonas spp showed antimicrobial susceptibility to the Tiger nut crude extract concentration of $10 \%$ and $20 \%$ with a Zone of Inhibition (ZOI) diameter of $18.0 \pm 0 \mathrm{~mm}$ and $18.5 \pm 1.5 \mathrm{~mm}$ respectively. Echerichia coli, Pseudomonas spp, Salmonella spp and Staphylococcus aureus showed susceptibility to the Irvingia gabonensis crude extract concentration of $10 \%$ and $20 \%$ with ZOI diameters of $13 \pm 2 \mathrm{~mm}, 15.5 \pm 0.5 \mathrm{~mm}, 16.5 \pm 1.5 \mathrm{~mm}, 16.5 \pm 0.5 \mathrm{~mm}$ and $15.5 \pm 0.5 \mathrm{~mm}, 19 \pm 0 \mathrm{~mm}, 18 \pm 1 \mathrm{~mm}$ and $15 \pm 0 \mathrm{~mm}$ respectively. The findings are in agreement with the study conducted by (1) who reported that Escherichia coli and Staphylococcus aureus were susceptible to Irvingia gabonensis crude extracts with the diameter of zones of inhibition ranging between $8 \mathrm{~mm}-23 \mathrm{~mm}$ for ethanolic ex- 
tract. The result also confirms the study by [10] who reported Pseudomonas aeruginosa and Staphylococcus aureus are susceptible to tiger nut from concentrations of $10-250 \mathrm{mg} / \mathrm{mL}$ and $125-250 \mathrm{mg} /$ $\mathrm{ml}$ respectively.

The study further revealed that the Minimum Inhibitory Concentration (MIC) value for Candida, E.coli, Pseudomonas spp, and Salmonella spp was 50\% concentration of the Tiger nut and Irvingia crude extracts. While the Minimum bacteriocidal concentration (MBC) of both crude extracts was 50\% concentration for Staphylococcus aureus only [1] reported that the Minimum Inhibitory Concentration (MIC) of Escherichia coli and Staphylococcus aureus ranged between $6.25 \mathrm{mg} / \mathrm{ml}-50 \mathrm{mg} / \mathrm{ml}$, while the Minimum Bactericidal Concentration (MBC) ranged between $12.5 \mathrm{mg} / \mathrm{ml}-50 \mathrm{mg} / \mathrm{ml}$ (Seukep et al. 2013) reported that the Cyperus esculentus exhibited antimicrobial activities depending of bacteria strains, with minimal inhibitory concentrations (MICs) values ranging from 64 to 1024 $\mu \mathrm{g} / \mathrm{ml}$.

\section{Conclusion}

Tiger nut (Cyperus esculentus) and bush mango (Irvingia gabonensis) contains chemical constituents which possess antibacterial activity against Candida, albicans, Echerichia coli, Pseudomonas spp, Salmonella spp and Staphylococcus aureus the causative agents of several infections. The chance to find antimicrobial drugs were apparent on both extracts, therefore, the plant could be a source of new antibiotics for treatment of diseases. Exploration of Bush mango and Tiger nut can have an economic impact in marketing and employment in Africa. Tiger nut and Bush mango is a source of raw materials for fruit juices, and it can also improve the treatments of microbes that are resistant to antibiotic currently in use.

The abundance of bush mango and tiger nut plants in Nigeria, and Africa continent should be explored because both plant extracts possess antimicrobial activity and may reduce the drug resistant and cost of treatment diseases. It is therefore recommended.

Pharmaceutical companies should explore it, not only for Antimicrobial activity. But also, food and beverages companies should explore it's for the production of fruit juices because of it nutritional benefits to humans. More research work should be done on Bush mango and Tiger nut.

\section{Conflict of Interest}

There was no conflict of interest in the course of carrying or reporting this study.

\section{References}

1. Nworie O, Orji J O, Ekuma UO, Agah MV, Okoli CS, et al. (2016) Antibacterial Activity of the Leaf and Stem Bark of Irvingia gabonensis (Bush Mango) Against Escherichia coli and Staphylococcus aureus. Global Journal of Pharmacology 10(1): 13-18.

2. Abaejoh R, Djomdi I, Ndjouenkeu D (2006) Characteristics of Tiger nut (Cyperus esculentus) tubers and their performance in the production of a milky drink. Journal of food process Preservation 30: 145-163.

3. Belewu MA, Abodunrin AO (2008) Preparation of kunun from an unexploited rich food source: tiger nut (Cyperus esculentus). Pakistan Journal of Nutrition 7: 109-111.

4. Chukwuma ER, Obiama N, Christopher OI (2010) The phytochemical composition and some Biochemical effect of Nigerian Tigernut (Cyperus esculentus. L) tuber. Pakistan Journal of Nutrition 9(7): 709-715.

5. Kuete, V, Wabo GF, Ngamerni B, Armelle TsafackMbaveng, RobertMetuno, et al. (2007) Antimicrobial Activity of the Methanolic Extract, Fractions and Compounds from the Sterm Bark of Irvingia gabonensis (Ixonanthaceae). Journal of Ethnophamacology 114(1): 54-60.

6. Abdulrahman F, Inyang LS, Abbah J, Binda L, Amos S, et al. (2004) Effect of Aqueous Leaf Extract of Irvingia gabonensis on Gastrointestinal Tract in Rodent. India Journal of Experimental Biology 42(8): 787-791.

7. Prakash N, Ragavan B (2009) Phytochemical observation and antibacterial activity of Cyperus esculentus. Science Life 28(4): 16-20.

8. Adeshina G, Onujagbe O, Onalopo J (2009) Comperative Antibacteria study on the root stem bark and leaf extract of clappertoniana. International Journal of Alternative Medicine 8(2): 649.

9. Malann YD, Anonymous K, Olarewaju CA (2014) Antiplasmodial Effect of Ethanolic Leaf Extract of Irvingia gabonesis on Plasmodium berghei in Mice. Global Journal of Current Research 1(3): 40-45.

10. Biradar S, VA KANGRALKAR, YUVARAJ MANDAVKAR, MEGHA THAKUR, NILESH CHOUGULE (2010) Antiinflammatory, antiarthritic, analgesic and anticonvulsant activity of Cyperus eculentus oils. International Journal of Pharmacy and Pharmaceutical Sciences 2(4): 2-6. 